\title{
The Youth Demographic: Opportunity and Challenge for Developmental Planning: A Zimbabwe Case Study
}

\author{
Kedmon Hungwe \\ Michigan Technological University \\ United States of America
}

\section{Doi:10.5901/jesr.2013.v3n6p119}

\begin{abstract}
Education and job creation are key instruments for facilitating the transition of youth and young adults to productive roles. This poses particular challenges in developing countries because they have relatively high population growth rates. The demographic pattern associated with high birth rates and low child mortality has been called the 'youth buldge' because it is characterized by large gains in the lower half of the population pyramid. Zimbabwe (previously known as Rhodesia) is presented as a case study where developmental priorities have not adequately supported the transition of youth to productive adult roles. The policy shortcomings originated in the colonial period and have continued after independence. The study is presented to make the case that countries that do not adequately support the transition of the young generation to productive adult roles risk debilitating social, political and economic instability.
\end{abstract}

Keywords: Youth bulge; educational policy; economy; governance; Zimbabwe.

\section{Introduction}

The preamble to the African Union Charter recognizes youthhood as both an asset and a developmental challenge. It has been noted that the youth faces marginalization from society through poverty, unemployment, underemployment, illiteracy, restricted access to health services, among other factors. Article 14 of the charter calls on member states to "recognize the right of young people to a standard of living adequate for their holistic development." Article 15 states: "Every young person shall have the right to gainful employment." Other rights include nondiscrimination, freedom of movement, freedom of association, and right to education of equality (African Union, 2009)

Education has been one of the key instruments for facilitating the transition of youth and young adults to productive roles. As economies have been transformed, the demand for formal education and training has escalated. Concurrently, populations have increased, with large gains in the lower half of the population pyramid. The resulting demographic pattern has been called a 'youth bulge.' A youth bulge occurs when there is combination of high fertility rates and declining infant mortality rates, and this has typically occurred in developing countries.

In 2008 Dhillon drew attention to the demographic youth bulge in the Middle East, which offered "a large pool of human capital which if used productively can usher growth and prosperity." The social and economic exclusion of the youth could create social strife (Dhillon, 2008; Cincota, Engelman \& Anastasion, 2003). Sub-Saharan Africa faces the similar challenges. The challenge of expanding opportunity comes at a time when the economic outlook for the continent is looking brighter. The region's economies are expected to average a growth of 5.6 percent in 2013 which has been a cause of optimism (Business Day, April 22, 2012). The trend is expected to continue and pick-up over the 2013-2015 period (World Bank, 2013). Cameroonian Finance Minister Alamine Ousmane Mey identified the key pillars of growth as "vast natural resources, youthful population and rapidly increasing middle class." Nigerian Finance Minister Ngozi Okonjo-I weala has also 
expressed optimism and has been quoted as saying: "For the first time, we are able to contribute to the global growth. We are in a good place." (Business Day, April 22, 2012).

Zimbabwe is presented as a case study of a country where developmental priorities have not adequately supported the transition of youth to productive adult roles. Policy shortcomings originated in the colonial period and have continued after independence. The consequences of the policy failture are examined.

\section{Zimbabwe Context: Historical Antecedents}

The origins of the formal education system in Rhodesia can be traced to the end of the 19th century when the British colonized the country. By 1900, about 18 Christian denominations were operating in Rhodesia. The colonial development policy was founded on racial segregation and white supremacy as the guiding principles. These principles were evident in educational policies. The development of government-sponsored schools is a case in point. In the 1920s, Herbert S. Keigwin, a government official working for the Native Department, persuaded the government to set up two state-run institutions to train Africans. Domboshava was established in 1920 and Tjolotjo established in 1921. Keigwin's work in education embodied a confluence of colonial ideas, drawn from local, regional and overseas (Keigwin, 1924). His primary interest stemmed from a desire to promote rural development through village industries such as basketmaking, chairmaking, pottery, and tilework which would not compete with European skills and products.

The Keigwin curriculum quickly provoked student resistance because of the restrictions on academic and practical skills. Towards, the end of 1921, students at Domboshava went on strike. "Twenty-nine boys of junior forms decided they were being kept back in their English by being refused a reader"1 (Lloyd, 1962). The students marched to the capital to confront the education official in charge and were successful in forcing changes in the curriculum. However, the initial adjustments did not satisfy them. There was a second strike in 1922. Forty-nine s students (out of 79) struck, "because they did not have long enough in school academic classes" (Lloyd, 1962). The unrest at Tjolotjo was more severe. The school was shut down in 1922 shortly after opening as the students demanded a curriculum better aligned with skilled and semi-skilled work (Summers, 1994). The school principal Alexander was forced to resign, and so was his successor, F. R. Mills. The situations at both Domboshava and Tjolotjo eventually settled, with the students having won the concession they demanded.

The Native Education Commission of 1925 concluded that the original idea of teaching the rudiments of knowledge had proved unworkable. "The Director of Native Development can hardly be blamed for this, " the report commissioners concluded, "except possibly for want of foresight in failing to appreciate the demand and necessity for a larger measure of literary training (S. R. G., 1925). The report continued: "It is clear that from the evidence of the pupils themselves that the [African) Reserves offer at present no market for their services and that they must look to European centres of industry for the utilisation of their acquirements" (p. 19). Keigwin resigned. He moved on to Sierra Leone where he unsuccessfully tried to introduce similar ideas. ${ }^{2}$

The cases of the two government schools show that, from the beginning, students were not passive recipients of school knowledge. Access to schooling increasingly became important as the economy was transformed. At the same time, students appraised schooling in relation to their perceived needs for good jobs in the changing economy.

\footnotetext{
${ }^{1}$ Reader means books for practicing reading.

${ }^{2}$ Keigwin was appointed Director of Education in Sierra Leone. From 1927 to 1930 he worked to introduce a plan of education based on the ideas he had developed in Southern Rhodesia. His plans met with resistance. He resigned in 1930. See Corby (1990).
} 


\section{Demographic Shifts and Economic Change}

The African population was estimated at 500,000 in 1901 . The estimate increased to $1,260,000$ in 1936. The first enumerated census was in 1961. The population then stood at $3,616,600$. The population growth rate averaged 3.8 percent between 1901 and 1969, when the last census before independence was conducted (see Mavambo, 1999). The population was 7,501,470 in 1982, 10.4 million in 1982, 11.6 million in 2002, and $12,973,808$ in 2012. As the population grew, migration from the rural areas to the cities has increased. The rural exodus first gathered momentum in the 1920s and was particularly notable for including young unaccompanied boys aged below $14 .^{3}$ The primary 'push factors' driving people out of the rural areas were congestion and declining agricultural productivity. The men and boys were joined by growing numbers of women and girls. White employers initially welcomed the increased supply of cheap labour, but they soon decided that juvenile workers were unreliable and "were not the blessing they had hoped they would be" (Grier, 2006, p. 111).

Table 1: Proportion of African males and females not engaged in rural economic activities (1958)

\begin{tabular}{|c|c|c|}
\hline Age group & \multicolumn{2}{|c|}{ Percentage absent } \\
\hline & Male & Female \\
\hline $15-19$ & 45.8 & 24.1 \\
\hline $20-24$ & 79.3 & 32.9 \\
\hline $25-29$ & 83.4 & 40.2 \\
\hline $30-34$ & 83.6 & 36.4 \\
\hline $35-39$ & 51.2 & 20.1 \\
\hline $40-44$ & 34.6 & 12.9 \\
\hline $45-49$ & 25.6 & 8.2 \\
\hline $50-54$ & 13.7 & 4.0 \\
\hline $55-59$ & 18.9 & 3.9 \\
\hline $60-$ plus & 2.7 & 1.6 \\
\hline
\end{tabular}

Source: Mitchell, J. C. (1961) Wage labour and African population movements in Central Africa.

Table 1 indicates the proportions of young people not participating in the rural subsistence economy in 1958. Some, among the 15-19 year olds would have been in school. However, as the figure 1 shows, attrition enrolment attritions were very high. Schooling cannot therefore account for the vast majority of young people who were absent from their rural homes. Young people migrated to seek work in mining and agriculture, and to a lesser extent in domestic work, commerce, industry, and the public service. Other young people migrated to other countries, mostly to South Africa where the majority worked on the mines. The majority of the people leaving the rural areas were under-employed, or not employed at all.

${ }^{3}$ Papers relative to the Southern Rhodesia Native Juveniles Employment Act, 1926, and the Southern Rhodesia Native Affairs Act of 1927. Presented by the Secretary of State for Dominion Affairs to Parliament by Command of His Majesty, April 1928. See also Grier (2006) 


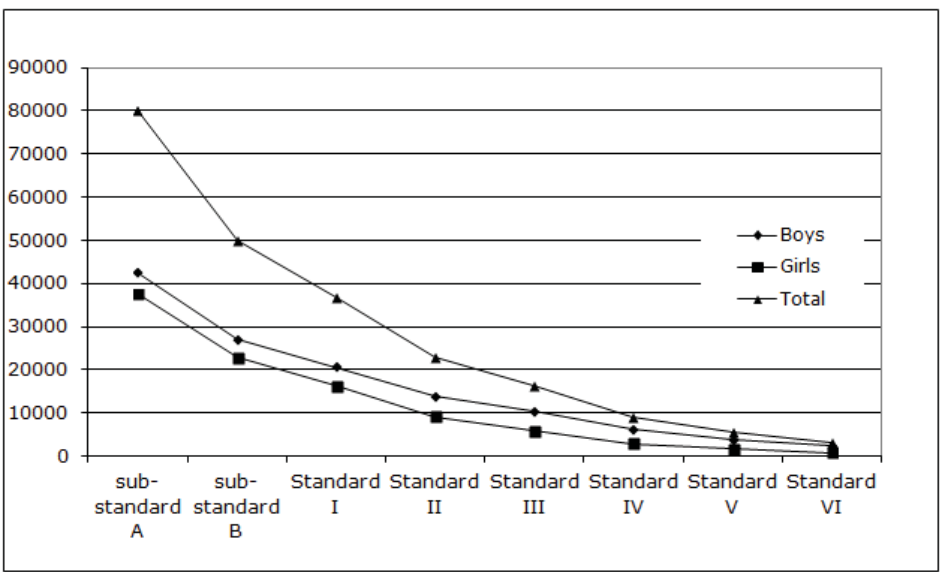

Figure 1: Enrolments in the African primary school by grade level, 1949

\section{Youth and the Political Crisis in the 1960s}

There was an economic boom in the post-second world war era, but the state opted to invest more in attracting and settling white settlers. At the same time the crisis in livelihoods in the rural areas intensified due to rising populations, and discrimatory land and agricultural polices that favored white settlers. The migration of people into the cities accelerated despite the lack of jobs, resources and infrastructure to accommodate the influx. Concurrently the demand for both schooling intensified. A warning of what was to come was signaled when, on April 16, 1958, some 60,000 African students who had failed to find school places in the crowded urban schools staged a demonstration (Parker, 1960). African youth were increasingly drawn to radical politics.

The most significant political youth initiative was the founding of a political formation called the City Youth League (CYL). The CYL was formed in 1955 by a youthful group in Salisbury that included George Nyandoro (29 years old), James Chikerema (30), Edison Sithole (20), and Dunduza Chisiza (25). Their plan was to launch a campaign of mobilization and active resistance. The movement found a receptive audience among the urban youths. The older generation of politicians was initially lukewarm, and in some cases hostile to the idea of the youth league. In his memoir, Maurice Nyagumbo, who was later to become a senior political figure and supporter of the CYL wrote, "The idea of a youth league did not appeal to me" (Nyagumbo, 1980). Nathan Shamuyarira, another prominent politician shared the same sentiment. The key turning point was the bus boycott of August 1956, described by Shamuyarira as the City Youth League's "greatest achievement" (Shamuyarira, 1965). The boycott lasted for three days.

The first significant case of youth-led political violence occurred during the bus boycott. Nathan Shamuyarira acknowledged the "burning of food stalls, wrecking of bus-shelters, looting, stoning, widespread rioting." Worse still, single women living in a city hostel were raped by the marauding youths. Remarkably, the senior nationalists Shamuyarira and Nyagumbo justified the sexual assaults, even going as far as to condemn those who expressed shock and dismay at the events. In his memoir, Nyagumbo (1980) wrote: 'Personally I had no regret for the incident. I actually believed that the girls deserved their punishment" (p. 105). Shamuyarira (1924) concurred. The end apparently justified the means. Henceforth, violence became a tool of political mobilization in Zimbabwe, with some of the bitterest conflicts occurring between rival African groups. The violence in the African townships was particularly sharp in the 1963-64 period. Shamuyarira has written that he was "heart-broken by the thuggery," at that time. At the same time, he has argued that the violence was a necessary instrument of political mobilization. 
It is difficult to mobilize and solidify support amongst the masses in Rhodesia without a certain amount of social and economic intimidation. I would put one condition: there must be majority support for the cause first. Intimidation of the majority by a few can never succeed; but intimidation of a few by a majority is a social weapon that has been used successfully. It also depends on the form it takes. While social ostracism and economic boycotts are justifiable, violence is not (p. 189).

Following a period of conflict between African political factions in the 1960s, the role of youth gradually shifted to armed resistance against the South Rhodesian government. A trickle of young people who were disillusioned with the country began to leave for military training with the encouragement of a political leadership. Among those who left in the early days were Josiah Tungamirai and Dumiso Dabengwa.

Josiah Tungamirai went to Mutero High school, graduating in 1964. From there he went to the capital Salisbury where he encountered racism. He left the country and joined the ranks of the guerrilla insurgency. Dumiso Dabengwa completed his secondary education at Tegwane Mission. Thereafter, he worked in the city of Bulawayo, and by the age of 20 he was taking an active interest in politics. He remembered: "Whites were paid 25 pounds and I was paid 12,50 pounds, yet we had the same qualification and I was allocated more work and responsibilities than them" (Sithole, 2009). In 1963, he left the country to receive military training.

The trickle turned to a flood in the 1970s. Margaret Dongo was only 15 years when, in 1975, she quit school and crossed the border into Mozambique to train as a guerrilla insurgent. Gloria Sibanda also left for Zambia. After the attainment of independence in 1980 she reflected in verse:

"As I grew up I started to know that without freedom there is no life, so I had to fight for freedom" (Bond-Stewart, 1984, p. 56).

The conclusion to be drawn from the preceding account is that youth were a significant, and leading partners in the emergence of radical politics in colonial Zimbabwe. The record from the writings of the nationalist themselves indicate that there was much youth violence, and that the violence was used as an instrument of control (Nyagumbo, 1980; Shamuyarira, 1965). When youths resorted to wanton violence for political ends, the nationalist leadership chose to coopt and channel that for political ends rather than seeking corrective measures.

\section{Socio-Economic and Political Factors after 1980}

The response of the Zimbabwe government to the youth bulge primarily focused on expanding the education sector. As an example, primary school enrolments increased from 1,235,994 in 1980 to 2,510,605 in 1997. Secondary school enrolment rose from 74,321 in 1980 to 806,126 in 1997. There were increases in teacher education, university education, and to a lesser extent in vocational and technical training. At the same time, the economic policies that were adopted at independence failed to grow the economy at a rate commensurate with developmental targets.

The economic problems had roots in the pre-independence period. In the period 1960-1979 the economy had been severely constrained. The United Nations imposed economic sanctions on Rhodesia following the Unilateral Declaration of Independence in 1965. Economic growth was also severely curtailed by the civil war (1973-1980), between the Rhodesian government and African nationalist fighters. At independence, the new Zimbabwe government maintained overly rigid controls on the economy, stifling growth. By 1989, the highly regulated economy was characterized by large deficits in balance of payments, budget deficits, and sluggish growth. The Zimbabwe Economic Structural Adjustment Programme (ESAP) was introduced to stimulate growth through deregulation, and cost recovery. 'Cost recovery' meant the removal or curtailment of government subsidies. Health services, agriculture, education, and food subsidies were among the areas targeted for cost recovery. The economic policy initiative was supported by the World Bank, the 
International Monetary Fund, and the African Development Bank who provided conditional loans.

The ESAP turned out to be an over-correction. Under the program, the GDP was projected to grow and steadily create jobs at an annual rate of 5 percent. The budget deficit was to be reduced from the 1991 level of 11 percent to 5 percent by 1995 (African Development Bank, 1997). The African Development Bank published a performance evaluation report at the end of 1997. The report noted that the implementation of ESAP had intensified poverty and efforts to cushion the impact of the program had been "too meager." Inflation, which stood at 7.1 percent in 1988, and 16 percent in 1990, accelerated under the program peaking at 40 percent in 1992. It declined to 26 percent in 1995 and 19 percent in 1997. The poverty level was determined to be "very high" with an estimated 62 percent living in households where income was not sufficient to meet basic needs (African Development Bank, 1997).

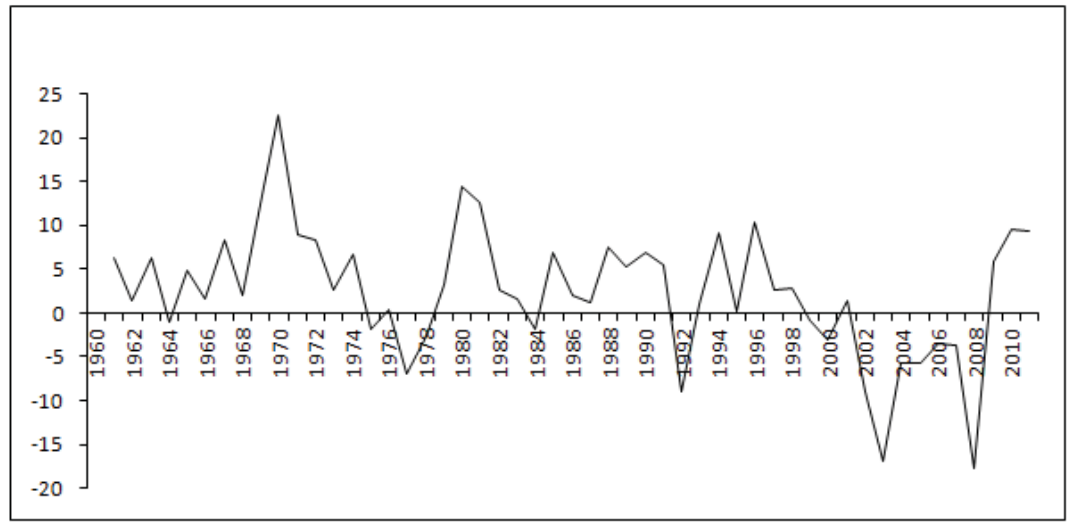

Figure 2: Zimbabwe GDP growth (annual percentage, 1960-2010)

\section{Seeds of Dissent}

The beginning of the ESAP period coincided with the emergence of political dissent from four main fronts. The first front of protest and dissent came from students in higher education who protested against economic policies and corruption in government. The second front was the trade union movement which was galvanized into action by the rising cost of living and increasing poverty. The movement was strongly opposed to the ESAP program. The third front was internal, within the ruling party itself. Edgar Tekere, a wartime ally of President Robert Mugabe was eventually expelled from the ruling party for outspoken criticism of corruption. The final front was the war veterans. Of the four movements, the war veterans have had the most significant impact on Zimbabwe particularly after the year 2002.

\section{War Veterans and the Politics of Confrontation and Cooption}

War veterans of the Zimbabwe civil war were a mostly youthful group made up of persons who had left Rhodesia to be trained as guerrilla fighters. They have mostly come from the ranks of the unemployed. Some had opted to leave school to go to war. A smaller proportion had held jobs before leaving the country. They had participated in a highly politicized war campaign, believing that their sacrifices would yield a better future for the communities from which they came, and for their own personal lives if they made it through the war. The high level of politicization and ideological consciousness was a key distinguishing feature of the group. As a result, they were always a potential political force in the life of the country. Kriger (2003) provides a helpful demographic profile of the war veterans, based on a 1980 survey, when the war ended. An 
estimated 14.6 percent were in the 15-18 year age group, 50 percent were in the 20-25 year age group, and about 35 percent were over 25 . The educational levels of the combatants were pretty low. An estimated 13 percent had no formal educational background, 69 percent had a partial or full primary education, and 17 percent had a partial secondary education. With regard to employment experience, 52 percent had no prior employment experience, 23 percent had worked as unskilled workers, and 16 percent had some semi-skilled work experience.

The confrontation between the state and the war veterans arose out of a sense of grievance on the part of the war veterans. They charged the government with corruption and willful neglect of the post-conflict welfare of the ex-combatants. The government had not been entirely negligent in attending to the welfare of the war veterans. At the end of the civil war, in 1980, some of the soldiers who fought in the nationalist ranks were absorbed into the new Zimbabwe defense forces. For the rest of them, the government provided a demobilizations package that included some technical training, further education, and a demobilization allowance of Z\$185 (US\$150) for 24 months. In the long run the plans carried out to integrate war veterans were ineffective or inadequate (Alao, 2012): Mhanda (2011) described the former fighters as falling into "extreme poverty and destitution" in the first decade of independence. In 1990, they formed the Zimbabwe National Liberation War Veterans Association (ZNLWVA) to press for their interests.

The turning point for the ZNLWVA association was in 1997 when the association launched an unprecedented challenge on President Mugabe in person forcing him to accede to their demands for lump-sum payments of Z $\$ 50,000$ (USD4000) to all former fighters and Z\$2000 (US\$150) monthly pensions (Sadomba, 2011). Provisions for health, education and burial were also agreed. The grants and pensions had not been budgeted for. Immediately following the agreement, the Zimbabwe dollar crashed on 13 November 1997 losing its value to the American Dollar by 73 percent. Mugabe, for his own part quickly recognized the danger that the war veterans posed for his position. He devised a strategy to coopt them. The path to cooption was eased by fissures and factions in the war veterans movement as well as allegations of corruption. The ruling party chose to back Chenjerai Hunzvi who emerged as the undisputed leader of the ZNLWVA. In March 2000, Hunzvi reported that the ZNLWVA had entered into a multimillion-dollar deal to mobilize and campaign for the ruling party (Norman, 2004; Tendi, 2010). In so doing, the movement essentially became the governing party's private army.

\section{Impact of the Governance Crisis on Livelihoods}

The economy experienced the most severe challenges after 2002, with the crisis peaking in 2008. Inflation had been steadily increasing in the 1990s. It accelerated from 2002 as the governance problem reached a crisis point. The Reserve Bank of Zimbabwe responded by increasing the money supply. In March 2007, the year-over-year inflation rate reached 2,200 percent, a critical hyperinflation benchmark (Hanke \& Kwok, 2009). The Reserve Bank aggravated the situation by printing money with no restraint. The rate of inflation peaked on 14 November 2008, with a daily rate of 98 percent, which means that prices were doubling every 24.7 hours (Hanke \& Kwok, 2009). At that point, the currency fell into disuse, as people simply determined that it had become worthless. The country has been using a mix of foreign currencies, with the US dollar as the primary currency.

\section{The Renewal of the Youth Militia Movement}

As the war veterans have aged, the ruling party has created ways of coopting unemployed and under-employed youths to supplement and energize the ranks of the militia. In September 2000, the Ministry of Youth Development Gender and Employment Creation published a document 
entitled, "The national youth policy - Zimbabwe." The document has become the cornerstone of the new policy. ${ }^{4}$ Youth is defined as the age range 10-30 years. The policy was couched in developmental terms in order to justify the use of state funds to support the initiative. However, youth on the program have received political education and military training (see for instance Reeler, 2003). Graduates from the program were first deployed during 2000 elections. They participated in coordinated violent attacks on the opposition party and invasions of white owned farms. They have been implicated in acts of rape, murder, mutilations, and intimidation. Political violence peaked during the election cycle of $2008 .{ }^{5}$ Since then the situation has been somewhat normal, but the infrastructure for violence has remained intact.

Table 2: Inflation Trends in Zimbabwe, 2008

\begin{tabular}{|l|r|}
\hline \multicolumn{1}{|c|}{ Date } & Year-over-year inflation rate (percent) \\
\hline January 2008 & 100,580 \\
\hline February 2008 & 164,900 \\
\hline March 2008 & 417,823 \\
\hline April 2008 & 650,599 \\
\hline May 2008 & $2,233,713$ \\
\hline June 2008 & $11,268,759$ \\
\hline July 2008 & $231,150,889$ \\
\hline August 2008 & $9,690,000,000$ \\
\hline September 2008 & $471,000,000,000$ \\
\hline October 2008 & $3,840,000,000,000,000,000$ \\
\hline 14 November 2008 & $89,700,000,000,000,000,000,000$ \\
\hline
\end{tabular}

Source: Hanke \& Kwok, 2009.

Political violence, economic hardship, and unemployment have forced Zimbabweans to leave their country in large numbers. Between 3 and 4 million Zimbabwe citizens live in the Diaspora (UNDP, 2010). The primary destination has been South Africa. Crush, Chikanda \& Tawodzera (2012) have conducted a survey on Zimbabweans migrating to South Africa that provides some insight on the impact of the economic and security situation. In 2005, 15 percent of individuals migrating into South Africa were in the 15-24 age group. The proportion of that group had increased to 31 percent in 2010. The proportion of the 25-39 year old was 56 percent in 2005, and rose slightly to 59 percent in 2010.

\section{Conclusion}

The case of Zimbabwe illustrates the fact that countries that lack economic, institutional, or political resources, or the political will to effectively integrate youth into society risk debilitating political and economic instability. The seeds of instability in Zimbabwe were sown during the colonial period. Young people initially sought to adapt to rapid changes by pressing for a relevant education, and by migrating from the rural areas to the new centers of employment. They also resorted to strike action and demonstrations. As the economic pressures intensified, youths, initially as independent

4 Zimbabwe national youth policy, http://planipolis.iiep.unesco.org/upload/Youth/Zimbabwe/Zimbabwe National Youth_Policy.pdf, Downloaded December 10, 2010.

${ }_{5}^{5}$ see for instance 2008 Human Rights Report: Zimbabwe. US Department of State. February 25, 2009 http://www.state.gov/j/drl/rls/hrrpt/2008/af/119032.htm 
agents, and latter as instruments of political factions turned to violence.

In the post-colonial period government policies did not yield a balance between investments in services such as education and economic growth and job creation. The imbalance precipitated an economic crisis. The ruling party's response compounded the crisis by creating a governance crisis that has severely undercut the developmental prospects of the country. The path to recovery requires the restoration of the rule of law and protection of basic human rights. The second necessity is a more systematic and aggressive pursuit of policies that engender economic growth and job creation.

\section{References}

African Development Bank (1997). Zimbabwe Economic Structural Adjustment Programme. Project Performance Evaluation Report. 9 December, 1997.

African Union, African youth Charter, Endorsed by AU heads of state in Bangui, Gambia, 2 July 2006. Came into force August 8, 2009. Addis Ababa, Ethiopia. http://www.unesco.org/new/en/social-andhuman-sciences/themes/youth/strategy-african-youth/african-youth-charter/

Alao, A. (2012). Mugabe and the Politics of Security in Zimbabwe. Montreal \& Kingston: McGill-Queen University Press.

Bond-Stewart, K. (1984). Young Women in the liberation struggle: Stories and poems from Zimbabwe. Harare: Zimbabwe Publishing House.

Business Day (April 22, 2013). Africa ready to add to global growth http://www.bdlive.co.za/africa /africanbusiness/2013/04/22/africa-ready-to-add-to-global-growth.

Cincotta, R. P., Engelman, R., \& Anastasion, D. (2003). The security demographic: Population and civil conflict after the Cold War. Washington DC: Population Actional International.

Corby, R. A. (1990). Educating Africans for Inferiority under British Rule: Bo School in Sierra Leone. Comparative Education Review, 34: 314-349.

Crush, J, Chikanda, A. \& Tawodzera, G. (2012). The third wave: Mixed migration from Zimbabwe to South Africa. Migration Policy Series No. 59. The Southern African Migration Programme.

Dhillon, N. (2008 йил 22-May). Middle East Youth Bulge: Challenge or opportunity. Retrieved 2011, 20July from Brookings: http://www.brookings.edu/speeches/2008/0522_middle_east_youth dhillon.aspx

Grier, B. (2006). Invisible Hands: Child Labor and the state in colonial Zimbabwe. Portsmouth, NH: Heinemann.

Hanke, S. H. \& Kwok, A. K. (2009). On the measurement of Zimbabwe's hyperinflation. Cato J ournal, 29: 353-364.

Keigwin, H. S. (1924) Segregation, NADA, 2: 52-57

Kriger, N. (2003). Guerrilla Veterans in Post-war Zimbabwe: Symbolic and violent politics, 1980-87. Cambridge and New York: Cambridge University Press.

Lloyd, B. W. (1962). Early History of Domboshava School: Period 1920-1939. NADA, 32, 4-13.

Mavambo, R. (1999). Death colonized: Historical adult mortality in Rhodesia (Zimbabwe). Zambezia, 26 (2)), 145-168.

Mhanda, W. (2011) 'The Role of War Veterans in Zimbabwe's Political and Economic Processes', 13 May, Solidarity Peace Trust: http://www.solidaritypeacetrust. org/1063/the-role-of-war-veterans/

Mitchell, J. C. (1961) Wage labour and African population movements in Central Africa. In K. M. Barbour \& R. M. Prothero (eds.). Essays on African population. London: Routledge and Kegan Paul.

Norman, A. (2004). Robert Mugabe and the Betrayal of Zimbabwe. Jefferson, NC: McFarland \& Company Nyagumbo, M. (19xx). With the people. Salisbury: Graham Publishing House.

Reeler, A. P. (2003) The role of militia groups in maintaining ZanuPF's political power. http://archive.niza.nl/docs/200303171414038719.pdf

Richard Cincotta, Robert Engelman, \& Daniele Anastasion (2003). The security demographic: Population and civil conflict after the Cold War. Washington DC: Population Action International.

S. R. G. (1925). Report of the Commission on Native Education. Salisbury: Government Printers. 
Sadomba, Z. W. (2011) War Veterans in Zimbabwe's revolution: Challenging neo-colonialism \& settler \& international capital. Suffolk, UK: James Curry

Shamuyarira, N. (1965). Crisis in Rhodesia. London: Hienemann.

Sithole, G. (2009, 13-July). The Biography of Dumiso Dabengwa . Retrieved 2011, 19-July from http://forum.newzimbabwe.com/index.php?/topic/4545-dabengwa-and-togogara-trained-underzipral

Sithole, G. (2009, 13-July). The Biography of Dumiso Dabengwa . Retrieved 2011, 19-July from http://forum.newzimbabwe.com/index.php?/topic/4545-dabengwa-and-togogara-trained-underzipral

Summers, C. (1994). Educational controversies: African activism and educational strategies in Southern Rhodesia,1920-1934. J ournal of Southern African Studies, 20: 3-25.

Tendi, B. (2010). Making history in Mugabe's Zimbabwe: Politics, intellectuals and the media. New York: Peter Lang.

UNDP (2010). The Potential Contribution of the Zimbabwe Diaspora to Economic Recovery, Working Paper No. 11. Harare: UNDP

World Bank (J une 26, 2013). World Bank Expects Muted Global Growth, Led By Developing World, June 26, 2013, http://www.worldbank.org/en/news/press-release/2013/06/12/world-bank-expectsmuted-global-growth-led-by-developing-world 